concern about possible insidious loss of neural or other bodily functions as a result of repeated nocturnal

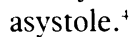

The frequent prolonged asystolic pauses in case 1 were considered sufficient indication for a pacemaker because of concern that the arrhythmia might progress, with the possibility of sudden death and adverse effects of chronic recurrent ventricular standstill. Whether stopping the patient from running would have successfully managed his condition is unknown, but he would have considered this to be an important deterioration in his quality of life.

Lifelong physical endurance training may result in an adaptive bradycardia and prolonged atrioventricular nodal conduction, which cannot be regarded as a purely benign physiological adaptation but may represent a pathological process causing symptoms, syncope, systemic embolism, or sudden death.' We chose to manage both patients with permanent pacemakers to maintain cardiac rhythm and allow them to continue their sporting activities. The improvement in performance in both patients would seem to support this policy.

1 Talan DA, Bauernfeind RA, Ashley WW, Kanakis C, Rosen KM. Twenty-four hour continuous ECG recordings in long distance runners. Chest 1982 82:19-24.

2 Ector $\mathrm{H}$, Verlinden $\mathrm{M}$, Vanden-Eynde $\mathrm{E}$, et al. Bradycardia, ventricular pauses, syncope and sports. Lancet 1984;ii:591-4.

3 Di Nardo-Ekery D, Abedin Z. High degree atrioventricular block in marathoner with 5-year follow-up. Am Heart $\mathcal{f}$ 1987;113:834-7.

+ Guilleminault C, Pool P, Moota J, Gillis AM. Sinus arrest during REM sleep in young adults. $N$ Engl $f$ Med 1984;311:1006-10.

Accepted 19 October 1988

\title{
Dietary maladvice as a cause of hypothyroidism and short stature
}

M Labib, R Gama, J Wright, V Marks, D Robins

Departments of Clinical Biochemistry and Clinical Nutrition and Paediatrics, St Luke's Hospital, Guildford, Surrey GU1

3NT

M Labib, MRCPATH, senior registrar

R Gama, MRCP, registrar

J Wright, MRCPATH, consultant

V Marks, FRCPATH, professor

D Robins, FRCP, consultant

paediatrician

Correspondence to: $\mathrm{Dr}$

Labib, department of

clinical biochemistry and

clinical nutrition.

Br.Med F 1989;298:232-3
Restrictive diets for children can be dangerous.' We describe a child who was given a restrictive diet for purported food sensitivity and presented with short stature and hypothyroidism due to dietary iodine deficiency.

\section{Case report}

A 4 year old boy was investigated for short stature. He had weighed $3200 \mathrm{~g}$ at birth ( $>25$ th centile) and had been fed cows' milk formula for six months, when solid food was introduced. When he was 2 his mother sought advice because of his poor appetite and constipation. His height and weight were below the third centile, but his rate of growth was normal. Both parents were short (father $152 \mathrm{~cm}$, mother $149 \mathrm{~cm}$ ). Despite treatment with lactulose he remained constipated, and a dietitian advised the mother to withdraw cow's milk and give him soya milk. During the next six months he developed diarrhoea and was referred by his general practitioner to a centre for "alternative therapies," where sensiti- vity to cows' milk, dairy products, goats' milk, eggs, chocolate, sugar, food additives, fish, beef, lamb, and pork was diagnosed. On advice his mother withdrew these items from his diet. During the next year his rate of growth dropped below the third centile.

The table summarises the investigations over time. On examination at 4 years 3 months his weight and height were below the third centile. Plasma electrolyte concentrations were normal, albumin concentration was $36 \mathrm{~g} / \mathrm{l}$, and radiological assessment gave a bone age of 3 years. Six weeks later results of pituitary function tests showed suboptimal growth hormone response but normal responses of cortisol, gonadotrophin, and prolactin. Basal plasma thyroid stimulating hormone concentration was raised but the response to thyrotrophin releasing hormone was normal.

Reassessment six months later showed an adequate response of growth hormone to glucagon. Plasma total and free thyroxine concentrations were low, and because the basal plasma thyroid stimulating hormone concentration was raised and the response to thyrotrophin releasing hormone exaggerated hypothyroidism was diagnosed. His autoimmune profile was normal, and thyroidal uptake of iodine- 131 was $68 \%$ at four hours (normal 11-30\%). Dietary assessment showed an average daily iodine intake of $40 \mu \mathrm{g} /$ day (recommended daily allowance $120 \mu \mathrm{g}$ ), and 24 hour urinary iodine excretion was low on two occasions $(6 \cdot 2$ and $30 \cdot 2 \mu \mathrm{g} / \mathrm{g}$ creatinine).

A normal diet including cows' milk supplemented with iodine $(40 \mu \mathrm{g} /$ day $)$ was reintroduced. After four

Results of biochemical investigations, weight, and height related to changes in diet

\begin{tabular}{|c|c|c|c|c|}
\hline Age & Treatment & Results of investigations & Height $(\mathrm{cm})$ & Weight $(\mathrm{kg})$ \\
\hline 2 Years 2 months & & & $77 \cdot 5$ & $9 \cdot 0$ \\
\hline 3 Years 0 months & Cows' milk substituted with soya milk & & $81 \cdot 3$ & $9 \cdot 9$ \\
\hline 3 Years 6 months & Restrictive diet introduced & & & \\
\hline 4 Years 3 months & & $\begin{array}{l}\text { Plasma growth hormone } 2.5 \mathrm{mU} / \mathrm{l} \text { basally, } 4.5 \mathrm{mU} / 1 \text { after exercise test. Plasma insulin-like } \\
\text { growth factor-1 } 100 \mathrm{U} / \mathrm{l} \text {. Plasma total thyroxine } 94 \mathrm{nmol} / 1\end{array}$ & $87 \cdot 5$ & $12 \cdot 0$ \\
\hline 4 Years 5 months & & $\begin{array}{l}\text { Insulin stress test }{ }^{\star} \text { showed cortisol } 215 \text { (basal) and } 872(\text { peak) nmol/l, growth hormone } 4 \cdot 4 \\
\text { and } 12.5 \mathrm{mU} / 1 \text {, prolactin } 248 \text { and } 1365 \mathrm{mU} / 1 \text {, luteinising hormone } 1 \text { and } 4 \mathrm{IU} / \mathrm{l} \text {, follicle } \\
\text { stimulating hormone } 1 \text { and } 6 \mathrm{IU} / 1 \text {, thyroid stimulating hormone } 6.4 \text { and } 20 \cdot 7 \mathrm{mU} / \mathrm{l} \text {. } \\
\text { Plasma total thyroxine } 106 \mathrm{nmol} / 1\end{array}$ & $87 \cdot 6$ & $12 \cdot 4$ \\
\hline 5 Years 0 months & & $\begin{array}{l}\text { Glucagon-propranolol test } \dagger \text { showed cortisol } 554 \text { (basal) and } 1010 \text { (peak) nmol/l, growth } \\
\text { hormone } 8.6 \text { and } 39 \cdot 0 \mathrm{mU} / 1 \text {, prolactin } 254 \text { and } 648 \mathrm{mU} / 1, \text { luteinising hormone } 1 \text { and } 6 \mathrm{IU} / \mathrm{l} \text {, } \\
\text { follicle stimulating hormone } 1 \text { and } 5 \mathrm{IU} / 1 \text {, thyroid stimulating hormone } 12 \cdot 4 \text { and } 62.6 \mathrm{mU} / \mathrm{l} \text {. } \\
\text { Plasma total thyroxine } 63 \mathrm{nmol} / 1 \text {. Plasma free thyroxine } 7 \cdot 8 \text { pmol/1 }\end{array}$ & $91 \cdot 0$ & $12 \cdot 5$ \\
\hline 5 Years 1 month & $\begin{array}{l}\text { Normal diet reintroduced, with iodine } \\
\text { supplementation } 40 \mu \text { daily for } 4 \\
\text { weeks }\end{array}$ & & $91 \cdot 0$ & $12 \cdot 5$ \\
\hline 5 Years 2 months & & $\begin{array}{l}\text { Thyroid function tests } \ddagger \text { showed total thyroxine } 102 \mathrm{nmol} / \mathrm{l} \text {, triiodothyronine } 2.4 \mathrm{nmol} / 1 \text {, free } \\
\text { thyroxine } 12 \cdot 7 \mathrm{pmol} / 1 \text {, and thyroid stimulating hormone } 4.8 \mathrm{mU} / \mathrm{l}(0 \text { minutes }), 24 \cdot 8 \mathrm{mU} / \mathrm{l} \\
\text { (20 minutes), and } 17.9 \mathrm{mU} / 1(60 \text { minutes })\end{array}$ & & \\
\hline 5 Years 3 months & & $\begin{array}{l}\text { Thyroid function tests } \ddagger \text { showed total thyroxine } 102 \mathrm{nmol} / 1, \text { triiodothyronine } 1.8 \mathrm{nmol} / 1 \text {, free } \\
\text { thyroxine } 15 \cdot 8 \mathrm{pmol} / 1 \text {, and thyroid stimulating hormone } 2 \cdot 2 \mathrm{mU} / 1(0 \text { minutes }), 14.4 \mathrm{mU} / 1 \\
(20 \text { minutes }) \text {, and } 11.1 \mathrm{mU} / 1 \text { ( } 60 \text { minutes })\end{array}$ & $93 \cdot 0$ & $14 \cdot 0$ \\
\hline
\end{tabular}

*Insulin $0 \cdot 15 \mathrm{U} / \mathrm{kg}$ and gonadotrophin releasing hormone $100 \mu \mathrm{g}$ and thyrotrophin releasing hormone $200 \mu \mathrm{g}$ all intravenously.

tGlucagon $0.5 \mathrm{mg}$ intramuscularly and propranolol $20 \mathrm{mg}$ orally and gonadotrophin releasing hormone $100 \mu \mathrm{g}$ and thyrotrophin releasing hormone $200 \mu \mathrm{g}$ intravenously.

$\ddagger$ Thyrotrophin releasing hormone $200 \mu \mathrm{g}$ intravenously.

Reference ranges: total thyroxine $60-160 \mathrm{nmo} / 1$; free thyroxine $9-28 \mathrm{pmol} / 1$; triiodothyronine $1 \cdot 2-3 \cdot 0 \mathrm{nmol} / 1$; basal thyroid stimulating hormone $<5 \cdot 0 \mathrm{mU} / 1$; insulin-like growth factor- $1120-900 \mathrm{U} / 1$. 
weeks plasma total thyroxine and thyroid stimulating hormone concentrations were normal. He had no diarrhoea or allergic symptoms and was more active and lively. Iodine supplements were stopped. After eight weeks his response to thyrotrophin releasing hormone was normal. He had gained $1.5 \mathrm{~kg}$ in weight and $2.0 \mathrm{~cm}$ in height.

\section{Comment}

The reversal of hypothyroidism in this child within eight weeks of a normal diet including cows' milk being reintroduced suggests that inadequate iodine intake was the cause of his hypothyroidism. Cows' milk and dairy products are an important source of dietary iodine. ${ }^{2}$ Their exclusion from his diet coupled with the consumption of large amounts of soya milk, which has been reported to cause hypothyroidism by increasing faecal loss of thyroxine, ${ }^{3}$ were probably the cause of the illness. The dramatic increase in growth rate after reintroduction of a normal diet suggests that his previous diet caused his growth failure either indirectly, due to hypothyroidism, or directly, due to undernutrition.

The criteria for diagnosing intolerance to cows' milk or multiple food allergy are strict. ${ }^{+}$Unorthodox procedures, usually used by doctors operating from private allergy clinics or centres of alternative medicine, have not been validated objectively, and their use has been criticised. This case shows that the inappropriate use of restrictive diets may lead to iatrogenic illness.

We thank Dr A B Parkes, department of medicine, University of Wales College of Medicine, for measuring urinary iodine excretion.

1 Tripp JH, Francis DEM, Knight JA, Harries JT. Infant feeding practices: a cause for concern. Br Med f 1979;ii:707-9.

Ne M Phillips DW Seasonal variations in dietary iodine incake and thyrotoxicosis. Hum Nutr Appl Nutr 1985;39A:213-6.

3 Shepard TH, Pyne GE, Kirschvink JF, McLean M. Soybean goiter. N Engl f Med 1960;262:1099-103.

4 Anderson $\mathrm{CM}$, Burke V. Other disorders of the small intestine associated with malabsorption. In: Anderson CM, Burke V, eds. Paediatric gastroenterology. Oxford: Blackwell, 1975:229.

5 David TJ. Unorthodox allergy procedures. Arch Dis Child 1987;62:1060-2.

Accepted 14 November 1988

\section{Necrosis of skin induced by coumarin in a patient deficient in protein S}

Vito Grimaudo, Felix Gueissaz, Jacques Hauert, Amira Sarraj, Egbert K O Kruithof, Fedor Bachmann

\section{Haematology Division, Department of Medicine and Department of Dermatology, University of Lausanne Medical School, CHUV, 1011 Lausanne,} Switzerland

Vito Grimaudo, $\mathrm{MD}$, research fellow

Felix Gueissaz, MD, consultant physician Jacques Hauert, PHD, biochemist

Amira Sarraj, MD, consultant physician

Egbert K O Kruithof, PHD, biochemist

Fedor Bachmann, MD ordinary professor

Correspondence to: $\mathrm{Dr}$ Grimaudo.

$\operatorname{Br} \operatorname{Med} \mathcal{f} 1989 ; 298: 233-4$
Necrosis of the skin induced by coumarin is a rare complication of oral anticoagulation that generally occurs in the initial phase of treatment. Why this process is localised to the skin remains unexplained. An association has been described between skin necrosis induced by coumarin and protein $\mathrm{C}$ deficiency. ' Protein $\mathrm{C}$ depends on vitamin $\mathrm{K}$ and exerts its anticoagulant effect by proteolytic inactivation of the clotting cofactors Va and VIIIa. ${ }^{2}$ Protein S, which also depends on vitamin $\mathrm{K}$, acts as a cofactor for activated protein $\mathrm{C}$.

In the initial phase of oral anticoagulation the concentration of protein $\mathrm{C}$ falls more rapidly than that of the other vitamin $\mathrm{K}$ dependent factors (except factor VII), resulting in a transient hypercoagulable state. This is more pronounced in patients deficient in protein $\mathrm{C}$ and is probably responsible for the development of thrombi in the microvasculature of the skin. We report a case of skin necrosis induced by coumarin in a patient with functional deficiency of protein $\mathrm{S}$ and normal concentrations of protein $\mathrm{C}$.

\section{Case report}

A 63 year old man, operated on for an aneurysm of the left superficial femoral artery, developed necrosis of the toes postoperatively. Prophylactic intravenous heparin was given and, after two days, replaced by nicoumalone at the following daily doses: $6,4,3,3,1$, 1 , and $2 \mathrm{mg}$. Three days later he developed a large ecchymosis over the left elbow $(25 \times 15 \mathrm{~cm})$ and a smaller one on the extensor surface of the right foot that rapidly became necrotic. Nicoumalone was stopped and subcutaneous heparin introduced; the lesions healed slowly.

On two occasions thereafter, oral anticoagulation was started at low, gradually increasing doses in combination with therapeutic doses of heparin according to a scheme recommended for patients with protein $\mathrm{C}$ deficiency. ${ }^{3}$ On the first occasion nicoumalone was introduced at $2 \mathrm{mg}$ daily and no further necrosis occurred, whereas on the second occasion it was restarted at $3 \mathrm{mg}$ daily and a small recurrence of necrosis was observed. On day 73 after the onset of skin necrosis his left leg was amputated above the knee. The table shows the results of laboratory investigations of plasma samples obtained on days $8,15,79$, and 142 .

Coagulation variables and $C 4 b$ binding protein concentration in patient with skin necrosis induced by coumarin

\begin{tabular}{|c|c|c|c|c|c|}
\hline \multirow[b]{2}{*}{ Variable } & \multirow{2}{*}{$\begin{array}{l}\text { Normal } \\
\text { range } \\
(\text { mean } \\
\pm 2 S D)\end{array}$} & \multicolumn{4}{|c|}{$\begin{array}{l}\text { Time after onset of } \\
\text { necrosis (days) }\end{array}$} \\
\hline & & 8 & 15 & 79 & $142^{\star}$ \\
\hline Thromboplastin time (\%) & $70-140$ & 65 & & 95 & 22 \\
\hline $\begin{array}{l}\text { Activated partial thromboplastin } \\
\text { time (s) }\end{array}$ & 26 & 33 & & 34 & 41 \\
\hline Antithrombin III activity $(\%)$ & $80-120$ & 120 & 120 & 115 & 105 \\
\hline Protein $\mathrm{C}$ activity $(\%) \dagger$ & $70-140$ & & 120 & 125 & \\
\hline Protein $C$ antigen $(\%) \ddagger$ & $63-134$ & 115 & 120 & 115 & 60 \\
\hline Total protein $S$ antigen $(\%) \neq 5$ & $56-150$ & 62 & 70 & 75 & 23 \\
\hline Free protein $S$ antigen $(\%) \neq$ & $52-157$ & $<1$ & $<1$ & $<1$ & $<1$ \\
\hline $\mathrm{C} 4 \mathrm{~b}$ binding protein antigen $(\%)$ & $68-140$ & 200 & 195 & 220 & 100 \\
\hline
\end{tabular}

*Patient being treated with oral anticoagulants.

t Measured by chromogenic assay after activation with Agkistrodon contortrix t

tMeasured by enzyme linked immunosorbent assay (ELISA) (Stago, France)

TTo promote dissociation of protein $\mathrm{S} / \mathrm{C} 4 \mathrm{~b}$ binding protein complex, samples were diluted 400 -fold and incubated for 18 hours at room

temperature before testing.

Measured by rocket immunoelectrophoresis.

\section{Comment}

Skin necrosis induced by coumarin has been described in association with protein $\mathrm{C}$ deficiency.' In our patient, however, protein $\mathrm{C}$ antigen and activity values were normal. Concentrations of total protein $S$ antigen were at the lower limit of the normal range when the patient was not being treated with coumarin and below normal during stable anticoagulation (day 142). ${ }^{+}$The free (active) portion of protein $S$ was consistently below the limit of detection of the assay. The skin necrosis was therefore associated with a functional protein $S$ deficiency.' In 10 members of the patient's family no abnormalities were found in protein $S$ concentrations.

Concentrations of total protein $S$ at the lower limit of the normal range could not explain the almost complete absence of free (active) protein S. In normal plasma there is an equilibrium between the free (active) form (about $40 \%$ ) and its complexed (inactive) form 